Gönderim Tarihi: 16.04.2018 Kabul Tarihi: 07.09.2018

\title{
NURSING HOME IN TURKEY: A REMEDY FOR THE CHANGING INTERGENERATIONAL RELATIONSHIPS OR A TOTAL INSTITUTION?
}

\author{
Pelin ÖNDER EROL* \\ TÜRKIYYE'DE HUZUREVİ: DEĞİŞEN KUŞAKLARARASI \\ ÍLIŞKILLERE BİR ÇARE Mİ YOKSA BÜTÜNCÜ BİR \\ KURUM MU?
}

\begin{abstract}
Currently, Turkish population has been ageing and the number of the elderly people who are placing into nursing homes has been increasing. Due to urbanization, women's increased participation in labour force and ideational change from collectivism to individualism, the nursing home, as one of the bureaucratic organizations taking over the previous functions of the family, has been emerged as a facet of population ageing. However, the issue on how and by whom the elderly care is performed is standing upon an ambiguous base in Turkey, where filial piety as a cultural norm has still been of great importance while modern lifestyles may restrain families from providing caregiving for their elderly members. Hence the issue concerned in this study can be approached from two distinct theoretical frameworks. Nursing homes in Turkey can be conceptualized as a remedy for the changing intergenerational relationships, as well as a total institution which reflects the very idea of institutional settings receiving negative public attitude.
\end{abstract}

Keywords: Intergenerational Relationships, Nursing Home, Total Institution, Elderly Care, Filial Piety

\section{Öz}

Günümüzde Türk nüfusu yaşlanmakta ve huzurevine yerleşen yaşlı sayısı artmaktadır. Kentleşme, kadının işgücüne katılımdaki artış ve toplulukçu kültürden bireyci kültüre geçişin yaratmış olduğu düşünsel değişim, ailenin önceden sahip olduğu işlevlerinin aktarıldığı bürokratik örgütlerden biri olan huzurevinin yaşlanan nüfusun görünür yüzlerinden biri olarak ortaya çıkmasına neden olmuştur. Ancak ebeveyne sayg1 kültürel normunun hala önemli olduğu, öte yandan modern yaşam tarzlarının aileleri yaşlı üyelerine bakım sağlamaktan alıkoyabildiği Türkiye'de yaşlı bakımın nasıl ve kim tarafindan gerçekleştirileceği konusu müphem bir temelde yer almaktadır. Buradan hareketle bu çalışmada ele alınan konuya iki ayrı kuramsal çerçeveden

* Dr. Öğr. Üyesi, Ege Üniversitesi, Edebiyat Fakültesi, Sosyoloji Bölümü, eposta: pelin.onder.erol@ege.edu.tr. 
yaklaşılabilir. Türkiye'de huzurevleri, değişen kuşaklararası ilişkilere bir çare olarak kavramsallaştırılabileceği gibi, toplum tarafindan olumsuz bir tutumla yaklaşılan bir kurumsal düzenleme fikrinin temelini yansıttığı düşünülen bir bütüncü kurum olarak da kavramsallaştırılabilir.

Anahtar Kelimeler: Kuşaklararası İlişkiler, Huzurevi, Bütüncü Kurum, Yaşlı Bakımı, Ebeveyne Saygı Normu

\section{Introduction}

Since 1950's Turkey has undergone a social transformation, partly due to modernization. The underlying motivations have predominantly derived from the modes of production, namely a shift from an overwhelmingly agrarian country to an industrial one. This, in turn, has brought forth a change in the social relations of production and, hence, in the relations within the family, at the micro scale. With modernization, families of the traditional/collectivistic cultures have been influenced by the modern/individualistic lifestyles, where family members take part in more democratic social interactions and have no more been defined through their position on hierarchical scale based on gender and age. The orientation towards this new tendency enabled the individual family members to live in an egalitarian environment with their own agency, however, in some cases at the very expense of elderly members, especially when they are in need of care.

In parallel with these changes, accompanying population ageing, the number of nursing homes and the number of institutionalized elderly people in Turkey has increased by $105,7 \%$ and $111,4 \%$, respectively, in a decade, namely between 2007 and 2017 according to the statistics provided by Ministry of Family and Social Policy (Aile ve Sosyal Politikalar Bakanlığ1, 2018), whereas old age population growth rate for the aforementioned time interval is $37,9 \%$, and the share of the old age population is $8,5 \%$ in 2017 , by drawing upon the statistics of Turkish Statistical Institute (TÜIK, 2017). Therefore, it can be inferred that Turkish population is getting older and the number of elderly people seeking for institutionalized care is increasing.

Studies conducted about elderly care in Turkey share a main feature: nursing homes are considered as a last option; instead aging in place, which is defined as "remaining living in the community" (Davey, de Joux, Nana and Arcus 2004: 133), is highly preferred over nursing homes by the Turkish elderly. Yet, change in material conditions gave rise to nursing homes as a necessity. Therefore, nursing home may be considered either as a remedy for the changing intergenerational relationships in social settings where individualistic life styles prevail, or 
as a total institution where the elderly people lose not only their agency and autonomy over their lives, but also the power derived from longestablished cultural norms prescribing that the elderly members of family retain the control over the material and non-material resources.

\section{The Nursing Home as a Remedy for the Changing Intergenerational Relationships}

The concept of intergenerational relationship is particularly important to shed light on the ways how families and the relations within them have changed over time. According to Kağıtçıbaşı and her colleagues (2010: 653), a key aspect of the concept "is the degree of support that is expected, aspired, considered proper, assumed and/or actually provided". Three different types of intergenerational relationship are identified in the literature, they are; solidarity, conflict and ambivalence (Lowenstein 2005). The degree of inconsistency between the assumed values and the actual practices with regard to elderly care determines which type is relied upon. However, a change in the practices would not necessarily mean a change in the values, and the reverse is also true. Therefore, we have to track changes in the social structure in order to develop an insight about the family change, with specific interest in elderly care in Turkey.

The Turkish family has experienced a change in family/kinship relations, as well as a change in structure. By drawing upon the findings of various research previously conducted at different time periods, Özbay (2015: 87) argued that the number of nuclear families proliferated and the pattern of co-residence decreased over time in Turkey. The relationship between the demise of co-residence within the extended family and decreasing family support for elderly people has been shown (Aboderin 2005).

Although such a pattern does not necessarily mean that intergenerational bonds are completely undermined for the Turkish case, it objectively indicates a general tendency towards a new type of living arrangement where the elderly person resides at a certain physical distance from where his/her adult child lives. This new type of living arrangement was defined by Stehouwer (1968 as cited in Rowland 1984: 78) as "“modified extended family' permitting 'intimacy at a distance"'. This main finding is consistent with the normative patterns of intergenerational living arrangements in Turkey. It is also widely held in the relevant literature that due to strong intergenerational bonds between generations in Turkey, elderly people are either co-residing with their adult children or living in their own houses, yet, within the same neighbourhood (Aykan and Wolf 2000; Aytaç 1998; Görgün-Baran 2003; Kalaycioğlu et al. 2003). Sociological research conducted upon Turkish families have consistently 
shown that intergenerational familial bonds are so strong that at least for a certain period of time throughout their lifecycle, most families have been in an extended family form in which different generations live together (Duben 2012; Özbay 2015; Timur 1972). This is also reflecting the idea of "transient extended family", a type of family conceptualization coined by Timur (1972). It should be noted here that studies about intergenerational relationships in Turkey had shown that exchange of emotional and material support between separately residing nuclear families of the same kin is extensively sustained (Aykan and Wolf 2000; Aytaç 1998). As Abadan-Unat (1986: 176) argued, this widespread practice indicates that a great number of families in Turkey are actually "functionally extended families".

Filial piety felt by the majority of people in Turkey is the reason why younger members of family become primarily responsible for caregiving for their elderly members. In East Asian cultures, the filial piety norm has a connotation that elder parents have a hierarchically higher status than their children, and care, obedience, greeting, pleasing and financial support are considered as integral parts of it (Cheung, Kwan, and $\mathrm{Ng}$ 2006: 618-619). Kağıtçıbaşı (1986) argued that even though there are many different aspects, filial piety is one of the few shared features of cultures marked by patriarchal ideology, including the Turkish culture. Filial obligation, felt subjectively by the younger generations, leads to an implicit intergenerational contract through which parents know for certain that they would be provided care by their adult children when they get old. Moreover, family plays an important role as a mediator between society and the individual, especially in countries where welfare provisions for the elderly are far from adequate. In underdeveloped countries, children are attributed high economic/utilitarian value partly because they are seen as old age security (Kağıtçıbaş1 1982). According to Cindoğlu and her colleagues (2008) support for the elderly people in Turkey is provided within families and kinship groups. This, concomitantly, causes elderly to be dependent upon the family and therefore lays a burden on families (Arun 2008; Kalaycığlu et al. 2003). Nevertheless, this causes a sort of intergenerational ambivalence, which points out to an ambiguity on deciding who should take care of the elderly members in contemporary society. This is in part because even in urban industrialized centres of Turkey a family-collectivistic culture still continues (Kağıtçıbaşı 2002: 24) and kinship idiom ultimately maintains its power among family members (Duben 2012: 98).

However, some research has already revealed that albeit the traditional values, the widely-held norm of keeping the elderly care within the 
family has been weakening in Turkey (Adak 2003). Due to structural differentiation experienced at macro scale in Turkey, caregiving for elderly members of the family has become problematic, especially for certain segments of society. It is also well-documented in the literature that family caregivers feel a burden especially when they have to deal with different types of responsibilities that must be performed simultaneously (Bowers 1987; Stroller and Pugliesi 1989; Montgomery, Gonyea and Hooyman 1985). As a result, although few in number, some families seek assistance from non-family institutional units in providing care for their elderly members. The explanations for the reasons lying behind this can be extended further for the Turkish case and, thus fall into three categories.

Firstly, internal migration from 1950's onwards caused extended families to split up into nuclear families. In addition to the structural differentiation leading to shrinking of the household size, a sort of cultural change has been observed especially among the second and third generation immigrants in terms of residential patterns (Iş1k 2002: 82). Given the fact that these generations have gradually internalized the values of urban culture; the corollary was an erosion of the former practice of co-residence.

Secondly, as mass education became more encompassing, Turkish women became more likely to have the opportunity to climb up the education ladder. Therefore, educated women have been emancipated from the private sphere based on gendered division of labour (Gök 2015) where they unquestionably have long taken the primary responsibility of care of family members.

Thirdly, cultures diffuse to each other through agents of globalization. Hence Western cultures which are marked by individualistic orientations may well diffuse into non-Western cultures which are blueprinted by familistic orientations. Therefore, it can be argued that individualism has been gradually replacing the long-established cultural norm of familism within many aspects of social world even in non-Western societies, as it is also true for the Turkish society.

All of these developments bring forth an ideational change regarding caregiving for the elderly people in the Turkish context. Today the widely-held opinion that placement of elderly parents into nursing homes is socially unacceptable has lost its former strength. As Onat and Tufan (2003: 73) also put it, value judgments which restrain the practice of providing shelter and care for the elderly people by non-family units has been weakened. Nevertheless, the issue of caregiving for the elderly in 
Turkey is still standing upon an ambiguous and slippery base from the point of view of adult children (Önder Erol and Gün 2018). On the one hand, most of the families remain being adhered to filial obligations and never consider nursing home as an alternative living arrangement for their elders. On the other hand, an increasing number of families conceive placement of their elders into nursing homes, either as inherently normal or as circumstantially inevitable in modern society.

In this context, when the elderly needs to be provided care, there occurs two options to be decided: either the elderly may be provided home-care or institutional care may be sought after. Despite the fact that the latter is an option which is rarely preferred, a non-negligible number of elderly people specifically from the urban centres have to be placed into nursing homes. This is also related with the fact that bureaucratic organizations take over many functions of family in modern society (Kongar 1970; Ogburn 1964). Caregiving for the family members who are in need of care, unarguably used to be one of those functions of the family in premodern society. However, especially due to the higher levels of women's participation in the labour force in modern industrialized societies, the long-established societal norm which prescribes that women are the primary caregivers in the family was dismantled. The result was a higher demand for institutional settings that would provide caregiving for the family member. In this context, in modern societies, where higher percentage of old people who require being cared for by others is exacerbated by the fact that no family member would be able to meet this need -no matter how willing they are to do so-, nursing homes increasingly become of greater importance.

Not surprisingly, some problems from the elderly people's point of view arise. In urban social settings where individualized life styles prevail, some families seek institutional care for their elders as a compensation for their inability to perform caregiving within the family. As a result, not only the feeling of being deserted by their family, but also the sui generis dynamics of nursing home may decrease the level of how much the nursing home elderly are satisfied with intra-familial relations (Önder Erol 2011). From this point on, we will specifically focus on the latter claim, where internal dynamics refer to social arrangements encompassing the nursing home institution.

\section{Nursing Home as a Total Institution}

By drawing upon a huge existing literature, it can be claimed that nursing homes can be regarded as total institutions from Goffman's methodological point of view (Cheng 2009; Gamliel and Hazan 2006; 
Hazan 1994; Khan 1999; Ryden 1984; Önder Erol 2011; Wiersma and Dupuis 2010). Therefore, the current part of this study proposes a theoretical framework for an insight on a taken for granted assumption that nursing homes in Turkey are considered as the last resort and are taken into consideration only if the family truly has no other options. Because caregiving for the family members has traditionally been performed within the household and it has recently and partially begun to be taken over by the bureaucratic organizations, it can be argued that the very nature of "total institution" is felt more profoundly by the nursing home elderly in some societies where collectivistic culture still prevails. This may be considered as the case in the Turkish society.

First of all, nursing home is suggested as a sort of total institution by Goffman (1961: xiii) in his well-known work Asylums:

"A total institution may be defined as a place of residence and work where a large number of like-situated individuals, cut off from the wider society for an appreciable period of time, together lead an enclosed, formally administered round of life".

Goffman (Ibid.: 4-6) states that the institutions that are established in order to provide caregiving for the incapable but harmless people, including the aged, the blind, the orphaned and the indigent ones fall into the first category. The rest is comprised of four frame categories: sanitaria-mental hospitals, prisons-concentration camps, army barrackswork camps and monasteries-cloisters. The shared features of total institutions are as stated below:

1. Sleeping, playing and working are all conducted in the same place and under the same authority.

2. All of the residents are treated alike and are supposed to do daily activities altogether.

3. These activities are scheduled by a rigid system.

4. Under a single rational plan, all of these activities are designed to meet the objectives of the institution.

Total institutions are composed of the inmates and the staff, who have different social worlds surrounding them. Inmate and staff worlds are performing in a functional social system where each has complementary roles (Rubin 2005: 844). Nevertheless, the distinct worlds cause a sort of implicit conflict between the groups. Inmates have limited space for interaction with the outside world, whereas staff are present within the institution only for a given period of time and hence typically maintain their social ties with the outside world. 
The most striking aspect of being institutionalized in a nursing home is that the decisions regarding the residents are taken by the staff instead of the residents themselves (Goffman 1961: 7-9). Likewise, Wiersma and Dupuis (2010: 288) state that since choice is limited in these facilities and the residents do not have any say over their own bodies, the residents are considered as institutionalized bodies. Ryden (1984) argues that even the control over their daily activities such as eating or having a bath causes an erosion of autonomy and hence decreases the level of morale among the nursing home residents. Hence, "they experience a civil death that denies them adultlike autonomy and control over their fate" (Rubin 2005: 844). With regard to the fact that all of the activities are performed in order to meet the objective of the institution, it can be claimed that nursing homes as total institutions dismiss individuality. Rather, it is replaced by a sort of collectivism where objectives of the larger entity are placed more value than those of the individuals. Moreover, "when residents or inmates attempted to display a sign of individuality, their attempts were treated as deviancy and were usually met with a range of negative sanctions" (Ronch 2004: 62). Unlike in civil context, in total institutions the residents lose the "personal economy of action", since they have to conform the regulations of predetermined schedules of everyday activities (Goffman 1961: 38). By drawing upon a larger study of quality of life in residential care settings, Cooney and Murphy (2009) argue that a rigid scheduling of activities in nursing homes and treating the residents alike lead to a routinization of the ethos of care.

"Ageing in place" is highly valued over other living arrangements for the elderly people all over the world. It is even more valuable when this "place" employs rights and responsibilities to those people. For example, elderly people in Turkey have long been valued because they have; owned the means of production plus other properties, contributed to the production processes as long as they were in good-health and played an important role in caregiving for grandchildren and performing other domestic tasks. Correspondingly, they have traditionally been respected and have enjoyed power in almost all of the decision-making processes regarding their families that are composed of their adult children and grandchildren.

In cultures where elderly people are valued due to their life experiences, placement into institutions may be considered as a sort of isolation from the outside world. The elderly people, who have previously been the ultimate authority within their family, experience a sort of ambivalence when they have to conform to a superordinate authority in a nursing home. Modernization theory of ageing suggests that in all modern 
societies old people have lower status than those in traditional societies (Tischler 1993: 234). In Turkey, which has currently been experiencing a transition from a traditional society to an industrial one, a social duality arises. Ogburn (1964) mentioned that a change in material culture leads to an adaptive culture in non-material terms. He specifically utilized the family as an example. As a response to material changes, the family makes some adjustments to fit them. However, when the changes in the non-material culture (i.e. family) do not synchronize with the changes in the material culture (i.e. life styles imposed by modernity), a cultural lag arises. Accordingly, the result would be a resistance to the social institutions that take over some previous functions of the family. This would account for the reasons why there exists a negative public opinion about nursing homes in Turkey. In fact, it is documented in the literature that nursing homes in Turkey are the places traditionally receiving negative public attitude (Işık 2002). Moreover, a nation-wide study conducted upon Turkish people aged between 18 and 64, who are clearly considered as non-elderly, has revealed that approximately $91 \%$ of all participants' preferences about where to live in their old age were any living arrangement other than the nursing home itself (TÜİK, 2006). Currently, only $0,4 \%$ out of all the Turkish elderly people live in nursing homes (Aile ve Sosyal Politikalar Bakanlığ1, 2015). Hence the "total institution" conceptualization becomes particularly useful for the Turkish case in explaining why and how nursing homes are still faced with resistance from a significant segment of society.

\section{Conclusion}

Turkish population is getting older; and increasingly more and more people are being admitted to nursing homes. These trends would make the "nursing home" an apparent facet of population ageing in Turkey. Urbanization, women's increased participation in labour force and ideational change from collectivism to individualism have altogether influenced the ways how elderly care has been approached. In current material conditions, which have greatly changed the intergenerational relationships, a number of families have to prefer placing their elderly members into nursing homes.

However, due to a cultural lag which points out to the fact that the nonmaterial culture lags behind the material culture derived from these material conditions, nursing homes are generally considered socially unacceptable. This is accompanied with the very fact that the institutionalized elderly, who have formerly been regarded as the authority in the family, have begun to be ruled under an authority and 
have lost their autonomy. Nevertheless, nursing homes may also be considered to be necessary and inevitable part of the modern society, where bureaucratic organizations take over many functions of the family for a relief from the burdens imposed by modern lifestyles.

In Turkey, where this cultural lag still exists, studying on nursing homes should be of particular importance. This is because although these institutions have emerged due to a necessity, they are approached with a negative public attitude. Especially when compared with its Western counterparts, Turkish culture regarding family has traditionally been based on the notion of filial piety, which is referred to the idea that children of the aged are the primarily responsible party for caring for their elderly parents. This notion, despite of the changing intergenerational relations, restrains people from admitting to nursing homes.

To sum up, due to the transition from traditional to modern society, a dual structure co-exists in Turkey. Throughout this transition, the family, as well as other social institutions, tries to make adaptive changes. Among these adaptations, the phenomenon of "nursing home" is standing upon an ambiguous point, since there is no agreed-upon and shared public opinion about it. On the one hand, it is considered to be a remedy for the changing intergenerational relationships within the family, and on the other hand it is considered to be a total institution which erodes the former individual agency of elderly people. By drawing upon the conceptualizations of "intergenerational relationship" and "total institution", this study is a theoretical attempt to shed light on the ways how nursing home in Turkey is regarded and to provide an insight for further studies relevant to the issue concerned.

\section{References}

Abadan-Unat, Nermin (1986). Women in the Developing World: Evidence from Turkey, Denver, Colorado: University of Denver.

Aboderin, Isabella (2005). "Changing Family Relationships in Developing Nations". The Cambridge Handbook of Age and Ageing. Ed. M. L. Johnson, V. L. Bengtson, P. G. Coleman, and T. B. L. Kirkwood. New York: Cambridge University Press. 469-475.

Adak, Nurşen (2003). "Yaşlıların Gayri Resmi Bakıcıları: Kadınlar”. Aile ve Toplum 2 (6): 81-89.

Aile ve Sosyal Politikalar Bakanlığı (2015). Engelli ve Yaşlı Hizmetleri Genel Müdürlüğ̈̈, available at: http://eyh.aile.gov.tr/data/ 
595de492290eac101 cfd1a92/Ek-\%20İ\%20Bazl1\%20Huzurevi\%20 Yaşl1\%20Kuruluş\%20Bakım\%20ve\%20İhtiyaç\%20Sayıları\%2020 15.xlsx, accessed on April 9th, 2018.

Aile ve Sosyal Politikalar Bakanlığı (2018). Engelli ve Yaşlı Hizmetleri Genel Müdürlüğü, "Engelli ve Yaşlı Bireylere Illişkin Istatistiki Bilgiler”, Istatistik Bülteni, Ocak 2018. available at: http://eyh.aile.gov.tr/data/56179f30369dc5726c063e73/BültenOcak2018(son).pdf, accessed on April 9th, 2018.

Arun, Özgür (2008). "Yaşlı Bireyin Türkiye Serüveni: Kaliteli Yaşlanma İmkânı”. Gaziantep Üniversitesi Sosyal Bilimler Dergisi 7 (2): 313-330.

Aykan, Hakan and Wolf, Douglas A. (2000). "Traditionality, Modernity, and Household Composition: Parent-Child Coresidence in Contemporary Turkey". Research on Aging 22 (4): 395-421.

Aytaç, Işı1k A. (1998). "Intergenerational Living Arrangements in Turkey”. Journal of Cross-Cultural Gerontology 13: 241-264.

Bowers, Barbara J. (1987). "Intergenerational Caregiving: Adult Caregivers and Their Aging Parents". Advances in Nursing Science 9 (2): 20-31.

Cheng, Sheung-Tak (2009). "The Social Networks of Nursing-Home Residents in Hong Kong”. Ageing \& Society 29: 163-178.

Cheung, Chau-kiu, Kwan, Alex Yiu-huen and Ng, Sik Hung (2006). "Impacts of Filial Piety on Preference for Kinship versus Public Care”. Journal of Community Psychology 34 (5): 617-634.

Cindoğlu, Dilek, Çemrek, Murat, Toktaş, Şule and Zencirci, Gizem (2008). "The Family in Turkey: The Battleground of the Modern and the Traditional". Families in a Global Context. Ed. I. C. Hennon, \& S. M. Wilson. New York: Routledge. 235-263

Cooney, Adeline and Murphy, Kathy (2009). "Ethos of Care and Environment in Long-Stay Care Settings: Impacts on Residents' Lives". Valuing Older People: A Humanist Approach to Ageing. Ed. Edmondson, Ricca \& Kondratowitz, Hans-Joachim Von. Bristol: The Policy Press. 161-176.

Davey, Judith, de Joux, Virginia, Nana, Ganesh and Arcus, Mathew (2004). Accommodation Options for Older People in Aotearoal New Zealand. Wellington, New Zealand: The Centre for Housing Research Aotearoa/New Zealand (CHRANZ). 
Duben, Alan (2012). Kent, Aile, Tarih. İstanbul: İletişim Yayınları.

Gamliel, Tova and Hazan, Haim (2006). "The Meaning of Stigma: Identity Construction in Two Old-Age Institutions". Ageing \& Society 26: 355-371.

Goffman, Erving (1961). Asylums: Essays on the Social Situation of Mental Patients and Other Inmates. New York: Anchor Books.

Gök, Fatma (2015). “Türkiye'de Eğitim ve Kadınlar”. 1980'ler Türkiyesi'nde Kadın Bakış Açısından Kadınlar. Ed. Ş. Tekeli. İstanbul: İletişim Yayınları. 161-175

Görgün-Baran, Aylin (2003). "Yaşlılığın ve Yaşamın Anlamı Üzerine Niteliksel Araştırma". II. Ulusal Yaşlılık Kongresi Bildiriler Kitabı. Denizli: Horoz Medya Yayınevi. 121-139.

Hazan, Haim (1994). Old Age: Constructions and Deconstructions. Cambridge: Cambridge University Press.

Iş1k, Caner (2002). Huzurevi ve Yaşlılık: İzmir Büyükşsehir Belediyesi Zübeyde Hanım Huzurevi Örneğinde. Unpublished Master's Dissertation. İzmir: Ege University Graduate School of Social Sciences.

Kağıtçıbaşı, Çiğdem (1982). The Changing Value of Children in Turkey. Papers of the East-West Population Institute No: 60. Honolulu, Hawaii: East West Center.

Kağıtçıbaşı, Çiğdem (1986). "Status of Women in Turkey: Cross-Cultural Perspectives" International Journal of Middle East Studies 18: 485-499.

Kağıtçıbaşı, Çiğdem (2002). "Cross-Cultural Perspectives on Family Change". Autonomy and Dependence in the Family: Turkey and Sweden in Critical Perspective. Ed. R. Liljeström, \& E. Özdalga. İstanbul: Swedish Research Institute in Istanbul. 19-39.

Kağıtçıbaşı, Çiğdem, Ataca, Bilge and Diri, Ayşesim (2010). "Intergenerational Relationship in the Family: Ethnic, Socioeconomic, and Country Variations in Germany, Israel, Palestine and Turkey". Journal of Cross-Cultural Psychology 41 (5-6): 652-670.

Kalaycıoğlu, Sibel, Tol, Uğraş Ulaş, Küçükkural, Önder and Kurtuluş, Cengiz (2003). Yaşlılar ve Yaşlı Yakınları Açısından Yaşam Biçimi Tercihleri, Türkiye Bilimler Akademisi Raporları No. 5, Ankara: TÜBİTAK. 
Khan, David L. (1999). "Making the Best of It: Adapting to the Ambivalence of a Nursing Home Environment". Qualitative Health Research 9 (1): 119-132.

Kongar, Emre (1970). "Türkiye'de Aile: Yap1s1, Evrimi ve Bürokratik Örgütlerle İlişkileri”. Amme İdaresi Dergisi 3 (2): 58-83.

Lowenstein, Ariela (2005). "Global Ageing and Challenges to Familes". The Cambridge Handbook of Age and Ageing. Ed. M. L. Johnson, V. L. Bengtson, P. G. Coleman, and T. B. L. Kirkwood. New York: Cambridge University Press. 437-442.

Montgomery, R. V., Gonyea, J. G., and Hooyman, N. R. (1985). "Caregiving and the Experience of Subjective and Objective Burden”. Family Relations 34 (1): 19-26.

Ogburn, William Fielding (1964). Social Change with Respect to Culture and Original Nature. Gloucester, Mass. England: Peter Smith.

Onat, Ümit and Tufan, Beril (2003). "Yaşlanma ve Sosyal Hizmet". II. Ulusal Yaşlılık Kongresi Bildiriler Kitabı. Denizli: Horoz Medya Yayınevi. 69-79.

Önder Erol, Pelin (2011). Sosyolojik Perspektiften Demografik Yaşlanma: Toplumsal, Ekonomik ve Politik Alanlarda Yaşlı Failliği. Unpublished PhD Dissertation. İzmir: Ege University Graduate School of Social Sciences.

Önder Erol, Pelin and Gün, Elif (2018). "Being an Adult Child of an Elderly Person Living in a Nursing Home: A Phenomenological Approach to the Turkish Case". Quality in Ageing and Older Adults 19 (2): 117-125.

Özbay, Ferhunde (2015). Dünden Bugüne Aile, Kent ve Nüfus. İstanbul: İletişim Yayınları.

Ronch, Judah L. (2004). "Changing Institutional Culture", Journal of Gerontological Social Work 43 (1): 61-82.

Rowland, D. T. (1984). "Old Age and the Demographic Transition". Population Studies 38: 73-87.

Rubin, Julius, H. (2005). "Total Institutions", Encyclopaedia of Social Theory. Ed. George Ritzer, California: Sage Publications Inc. 843845.

Ryden, Muriel B. (1984). "Morale and Perceived Control in Institutionalized Elderly”. Nursing Research 33 (3): 130-136. 
Stroller, Eleanor Palo and Pugliesi, Karen L. (1989). "Other Roles of Caregivers: Competing Responsibilities or Supportive Resources". Journal of Gerontology: Social Sciences 44: 231-238.

Timur, Serim (1972). Türkiye'de Aile Yapısı. Ankara: Hacettepe Üniversitesi Yayınları.

Tischler Henry L. (1993). Introduction to Sociology. Fort Worth: The Hartcourt Press.

TÜİK (Türkiye İstatistik Kurumu) (2006). Aile Yapısı Araştırması Veri Tabanı, available at: https://biruni.tuik.gov.tr/aileyapidagitimapp /aileyapi.zul, accessed on February 6th, 2018.

TÜİK (Türkiye İstatistik Kurumu) (2017). Adrese Dayalı Nüfus Kayıt Sistemi, available at: https://biruni.tuik.gov.tr/medas/?kn $=95 \&$ locale $=$ tr, accessed on April 9th, 2018.

Wiersma, Elaine and Dupuis Sherry, L. (2010). "Becoming Institutionalized Bodies: Socialization into a Long-Term Care Home", Journal of Aging Studies 24: 278-291. 